\title{
Academic Achievement and Conceptual Understanding of Electrodynamics: Applications Geoelectric Using Cooperative Learning Model
}

\section{Rizqi Prastowo"1, Syamsul Huda ${ }^{2}$, Rofiqul Umam ${ }^{3}$, Kittisak Jermsittiparsert ${ }^{4}$, Andika Eko Prasetiyo $^{5}$, Hasan Said Tortop ${ }^{6}$, Muhamad Syazali ${ }^{7}$}

${ }^{1}$ Department of Mining Engineering, Institut Teknologi Nasional, Yogyakarta, Indonesia

${ }^{2}$ Institut Agama Islam Negeri Kediri, Kediri, Indonesia

${ }^{3}$ School of Science and Technology, Kwansei Gakuin University, Japan

${ }^{4}$ Social Research Institute, Chulalongkorn University, Pathum Wan, Bangkok 10330, Thailand

${ }^{5}$ Graduate School of Humanities and Social Sciences, University of Melbourne, Australia

${ }^{6}$ Istanbul Esenyurt University, Esenyurt/ İstanbul, Turkey

${ }^{7}$ Department of Mathematics Education, Universitas Islam Negeri Raden Intan Lampung, Indonesia

*Corresponding Address: rizqi@ sttnas.ac.id

\begin{tabular}{|c|c|}
\hline Article Info & ABSTRACT \\
\hline Article history: & dents' comprehension of the theory is often implemented as an effort \\
\hline $\begin{array}{l}\text { Received: June } 7^{\text {th }}, 2019 \\
\text { Accepted: October } 12^{\text {nd }}, 2019 \\
\text { Published: October } 30^{\text {th }}, 2019\end{array}$ & $\begin{array}{l}\text { to improve their achievements. However, other learning processes are } \\
\text { rarely carried out by teachers, such as the practice or tools uses as the } \\
\text { lesson application. The purpose of this study is to analyze the learning } \\
\text { effectiveness by applying the geophysical surveys practice method or }\end{array}$ \\
\hline $\begin{array}{l}\text { Keywords: } \\
\text { cooperative learning; } \\
\text { environmental geophysical } \\
\text { survey; } \\
\text { geoelectric; } \\
\text { rock resistivity; } \\
\text { TGT. }\end{array}$ & $\begin{array}{l}\text { the use of environmental geophysics tools. The assessment of students' } \\
\text { abilities is based on the interpretation results of environmental } \\
\text { geophysical survey data and the presentations and discussions about the } \\
\text { results of interpretation. The TGT Cooperative learning model was used } \\
\text { with a quasi-experimental method and quantitative design. Data } \\
\text { collection was carried out using a series of research instruments in the } \\
\text { form of questionnaires. The results of the study were based on } \\
\text { comparisons between the experimental class and the control class. The } \\
\text { results show that the experimental class has excellent findings. 1) Based } \\
\text { on the results of the post-test, the TGT cooperative learning method is } \\
\text { very effective in this study, because teamwork can maintain students' } \\
\text { enthusiasm and understanding during the learning process. 2) Retrieval } \\
\text { of field data makes students better understand the application of } \\
\text { geoelectric concepts and determination of rock resistivity. }\end{array}$ \\
\hline
\end{tabular}

(C) 2019 Physics Education Department, UIN Raden Intan Lampung, Indonesia

\section{INTRODUCTION}

Outdoor learning is a teaching and learning activity that directed towards students facing the object of study. In some developing countries, it experiences symptoms of reducing time for students to study outside the classroom (Becker, Lauterbach, Spengler, Dettweiler \& Mess, 2017). The tradition of learning and curriculum design does not pay attention to learning activities outside the school and is limited to extracurricular activities, in contrast to developed countries that have paid attention to outdoor learning activities even early on (Pleasants, 2009).

The approach to learning outside the classroom uses outdoor settings as a means. The learning process using nature as a 
medium seen as very useful in knowledge management, where everyone will be able to feel, seeing can even do it themselves so that the transfer of knowledge based on experience in nature can be felt, translated, developed based on capabilities. The selection of outside-class learning activities refers to the experience cone of Dale, as proposed by Rickinson et al (2004). Direct Purposeful Experience is the experience of students getting a result of their activities. Students experience feel for themselves, everything related to achieving goals. Students relate directly to the object to study without using an intermediary because students get directly into concrete so that it will have high accuracy (Y1ldirim \& Akamca, 2017).

The teaching and learning process is often performed only by deepening the theory and discussing the answer to the questions. However, to increase students' achievements, many factors can support the level of students' success (Bosschaart, Schee \& Kuiper, 2016). To achieve students' achievements (Cutter-mackenzie \& Edwards, 2013), teachers use a variety of teaching methods, such as explanations of the theory, work on examples of questions, discussions, and demonstrations (Amato \& Krasny, 2011) of the experimental tools use (Abdurrahman, Saregar \& Umam, 2018). The most widely accepted and practiced methods are theoretical explanations and work on questions sample (Meadows, 2016).

Although the direct teaching method, such as the direct explanation from teachers and working on questions become the most popular method in the educational field, many scholars argue that those methods are not enough to help students' (Abdurrahman, Saregar \& Umam, 2018) deep understanding of a material concept (Hines, Hungerford \& Tomera, 2010). As an effect, it leads to the idea of teaching methods by using various methods (multi-methods) to improve the learning process as well as students' understanding. Even so, it should be noted that the effectiveness of a learning method depends on the type of subjects (Dunlap \& Liere, 2014).

In the case of environmental geophysics lessons, teamwork method is necessary, particularly regarding measuring or using geophysical tools, data interpretation, and collaboration in discussing the interpretations results in groups (Cuttermackenzie \& Edwards, 2013). One of the learning models used to improve students' understanding of collaborative learning is cooperative learning. Cooperative learning is a continuous learning method (Abdullah, 2010) which is accompanied by feedback followed by evaluation (Dunlap, 2010).

The cooperative learning model is a learning model by forming small groups (Tan \& So, 2018). In those small groups, students who have different understandings are demanded to teach one another (Amato \& Krasny, 2011). This model can produce more understanding compared to individual learning methods which students only receive an explanation from teachers (Dubois \& Krasny, 2016). Besides, in many studies, the cooperative learning method has proven can improve significant achievements in the fields of science (Parmin, Nuangchalerm \& El, 2019) and other relevant fields such as; arts, humanities (Amato \& Krasny, 2011), and social sciences. Cooperative learning also improves students' positive attitudes towards learning (Zaky, Islami \& Nuangchalerm, 2018), enhances social relations (Tan \& So, 2018), and builds students' high self-esteem and cohesiveness (Yumuşak, 2015). Cooperative learning can also be expressed in learning strategies where students work together to achieve learning targets (Dubois \& Krasny, 2016).

The TGT cooperative learning method is a method in which students are divided into heterogeneous groups (Abdurrahman, Saregar \& Umam, 2018). In this method, students play several games based on the instructional material given (Smith, 2019). Scores are given individually and 
collectively as well (Gillies, 2016), however, only team scores are considered as the measurement of winning and losing (Lestari, et al 2019).

This study aims to provide insight into teacher or lecturer who can use the finding to develop attitudes towards the use of cooperative learning methods, particularly the methods which require teamwork, such as TGT. Besides, the observation of TGT cooperative learning method effectiveness is completed by giving special treatment to the experimental class. The test results of the experimental class will be compared with the control class. Thus, the comparison of learning outcomes will determine the effectiveness of the TGT cooperative learning method.

\section{METHODS}

This study uses a quasi-experimental method with quantitative design (Numeric and statistics). Data collection was carried out using a series of research instruments in the form of tests/questionnaires. The collected data is then converted using predefined categories/criteria. The quality of quantitative research is determined by the number of research respondents involved. Sample data were obtained from 20 students divided into 2 classes, which are control class and experimental class. The pre-test was given before the geophysical survey aiming to identify the students' initial ability in comprehending geophysical lessons, particularly the topic of electrodynamics. Furthermore, after the geophysical survey was distributed, the data of students' understanding of the environmental geophysical, particularly in the electrodynamic topic and determination of rock resistivity, were obtained from the students' results of presentation, discussion (Wekke, et al., 2019), and post-test. In this study, the test was given in the form of 10 essay questions (Table 1).

Also, an assessment regarding students' understanding in the presentation and discussion of the interpretation results was carried out to find out to what extent students understanding (Siregar \& Kurniawan, 2018), particularly the control class in distinguishing rock resistivity and in explaining the distribution of rocks based on the geoelectric mapping.

Table 1. Treatment of the study

\begin{tabular}{lcc}
\hline \multicolumn{1}{c}{ Name of the activities } & Experiment Class & Control Class \\
\hline $\begin{array}{l}\text { The Strengthen of electrodynamic theory, the discussion of } \\
\text { questions }\end{array}$ & $\mathrm{O}$ & $\mathrm{O}$ \\
\hline Pre-test (10 questions in for of essay) & $\mathrm{O}$ & $\mathrm{O}$ \\
\hline $\begin{array}{l}\text { Implementation of environmental geophysical surveys } \\
\text { (Measurement of rock resistivity using geoelectric devices) by } \\
\text { applying the TGT cooperative learning method }\end{array}$ & $\mathrm{O}$ & $\mathrm{X}$ \\
\hline $\begin{array}{l}\text { the discussion of geoelectric measurement results (discussion } \\
\text { forum) }\end{array}$ & $\mathrm{O}$ & $\mathrm{O}$ \\
\hline Post-test & $\mathrm{O}$ & $\mathrm{X}$ \\
\hline
\end{tabular}




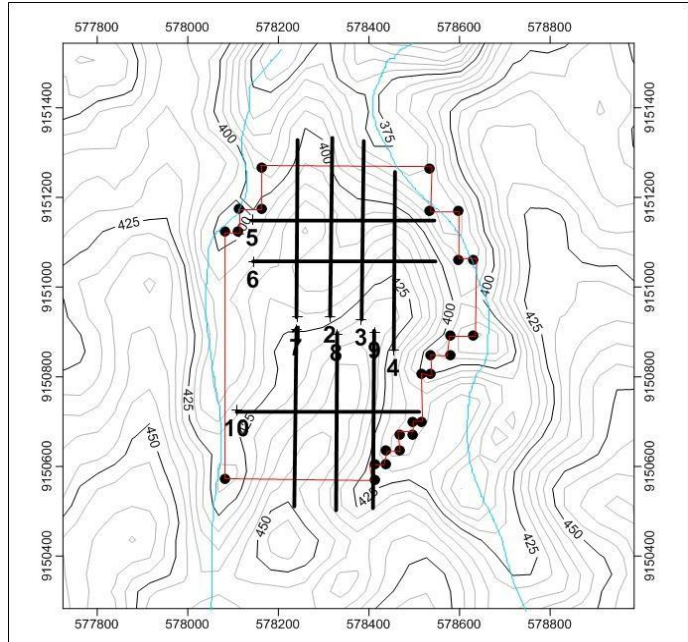

Figure 1. Geoelectric research survey design map

The practice study of environmental geophysical is carried out in the area of Morang Village, Madiun City, East Java, Indonesia. The research area is a potential area for the mining of building materials. Thus, the results of the research in the form of geoelectric interpretation can be used as a distributional map of mining materials that can help the residents.

The path shape of the environmental geophysical survey using geoelectric devices can be seen in Figure 1.

In this study, the configuration of the geoelectric method used is a dipole-dipole with both equal electrode spaces. However, the space between the electrode current and the electrode potential is made larger and measured repeatedly (Siregar \& Kurniawan, 2018). The stages of measurement data taking in the field are as follows.

a. Plug the electrode on the ground surface with a space of $20 \mathrm{~m}$, and spread the cable of $380 \mathrm{~m}$, with the number of $\mathrm{n}$ is 10.

b. The cable is stretched as the transmission of current and potential which connects between electrodes and resistivity meter tools.

c. After four electrodes are connected with a resistivity meter, then the measurement is ready.

d. Record the electric current and voltage which arise after the current is injected into the ground.

\section{RESULTS AND DISCUSSION \\ Results}

Normality test based on the results of the pre-test

Hypothesis:

$H_{0}$ : Data spreads normally

$H_{1}$ : Data does not spread normally

Table 2. The tests of normality

\begin{tabular}{cccccccc}
\hline & \multirow{2}{*}{ Class } & \multicolumn{2}{c}{ Kolmogorov-Smirnov } & \multicolumn{3}{c}{ Shapiro-Wilk } \\
\cline { 2 - 7 } & Statistic & df & Sig. & Statistic & df & Sig. \\
\hline \multirow{2}{*}{$\begin{array}{c}\text { Learning } \\
\text { outcomes }\end{array}$} & Control Class & .160 & 10 & $.200^{*}$ & .942 & 10 & .575 \\
& $\begin{array}{c}\text { Experiment } \\
\text { Class }\end{array}$ & .168 & 10 & $.200^{*}$ & .918 & 10 & .338 \\
\hline
\end{tabular}

Based on the data in Table 2, the probability of Kolmogorov Smirnov's output for the control class and the experimental class is 0.200 and 0.200 respectively. Since the value of Asymp. Sig. > 0.05, then $\mathrm{H}_{0}$ is accepted or both the data are normally distributed so that one of the normal assumptions of the $\mathrm{T}$ Test is fulfilled.

\section{Homogeneity test based on the pre-test} results

Hypothesis:

$H_{0}$ : The two sample variances are the same

$H_{1}$ : The two sample variances are not the same 
Table 3. Test of homogeneity of variance

\begin{tabular}{llcccc}
\hline & & $\begin{array}{c}\text { Levene } \\
\text { Statistic }\end{array}$ & df1 & df2 & Sig. \\
\hline \multirow{3}{*}{$\begin{array}{l}\text { Learning } \\
\text { outcomes }\end{array}$} & Based on Mean & .859 & 1 & 18 & .366 \\
& Based on Median & .966 & 1 & 18 & .339 \\
& Based on Median and with & .966 & 1 & 17.343 & .339 \\
& adjusted df & .843 & 1 & 18 & .371 \\
\hline
\end{tabular}

Based on table 3 , results obtained from the test of homogeneity of variances in the Lavene Test Statistics, the value of sign = 0.366 . The value is more than 0.05 , which means accepting $\mathrm{H}_{0}$ so that it can be concluded that the two sample variances are the same or homogeneous (Haq, Najmonnisa, \& Saad, 2015). Based on the test results of normality and homogeneous, the distributed data are normal and homogeneous. Therefore, the prerequisite test for the T-test is fulfilled so that the calculation is continued on the T-test.

\section{T-test based on pre-test results}

Hypothesis:

$H_{0}$ : The average learning outcomes of the two classes are the same

$H_{1}$ : There are differences in the average learning outcomes of both classes.

Table 4. Independent samples test

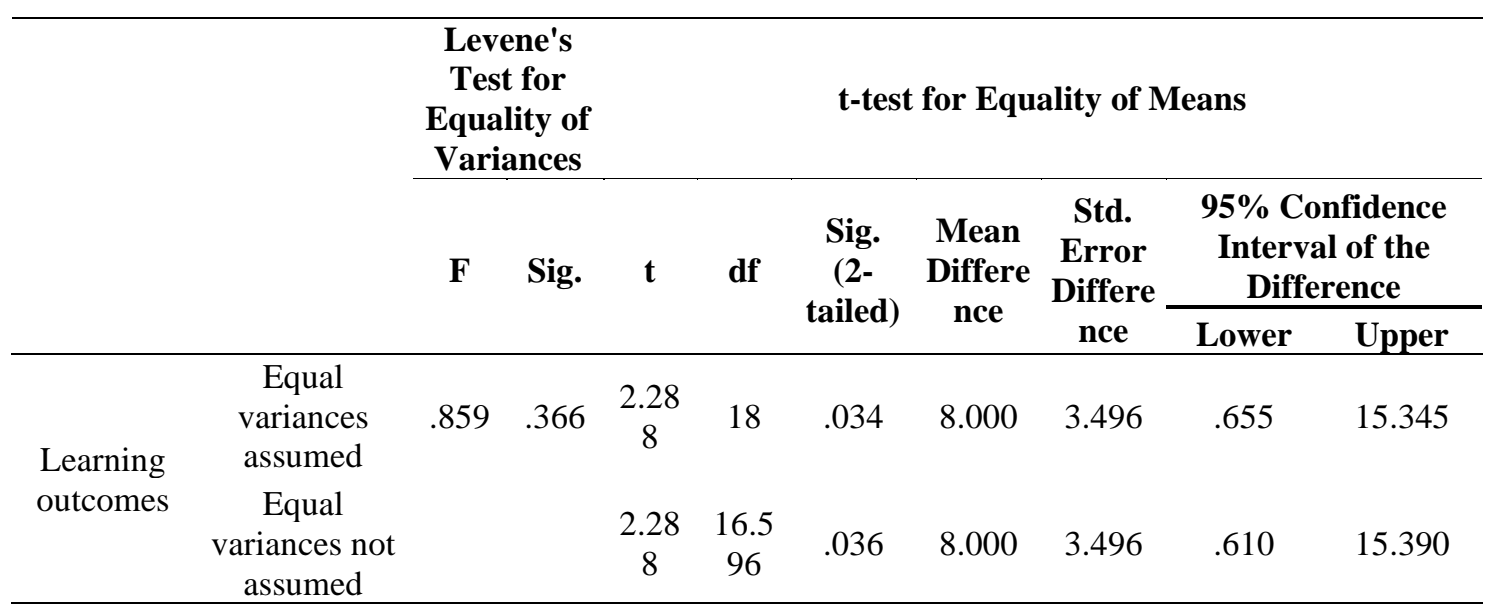

Based on table 4 , the sign value obtained $=0.034<0.05$, thus $\mathrm{H}_{0}$ is rejected, it means that there is a difference in the average learning outcomes of both classes.

Based on the T-test, it was received that there were differences in the average learning outcomes of both classes. However, the learning results obtained have not shown maximum results (Pisanpanumas, \& Yasri, 2018). Also, the pre-test value in the control class was higher than the experimental class. Therefore, there is a need for treatment in the experimental class to obtain better and maximum results (Maneejak \& Yasri, 2018). The next stage is giving treatment to the experimental class and then analyze again whether there are still differences in the average after the treatment in the experimental class (Putra, 2015). Also, to analysis whether the given treatment is successful or not to improve the experimental class scores (Mehta \& Kulshrestha, 2014). 


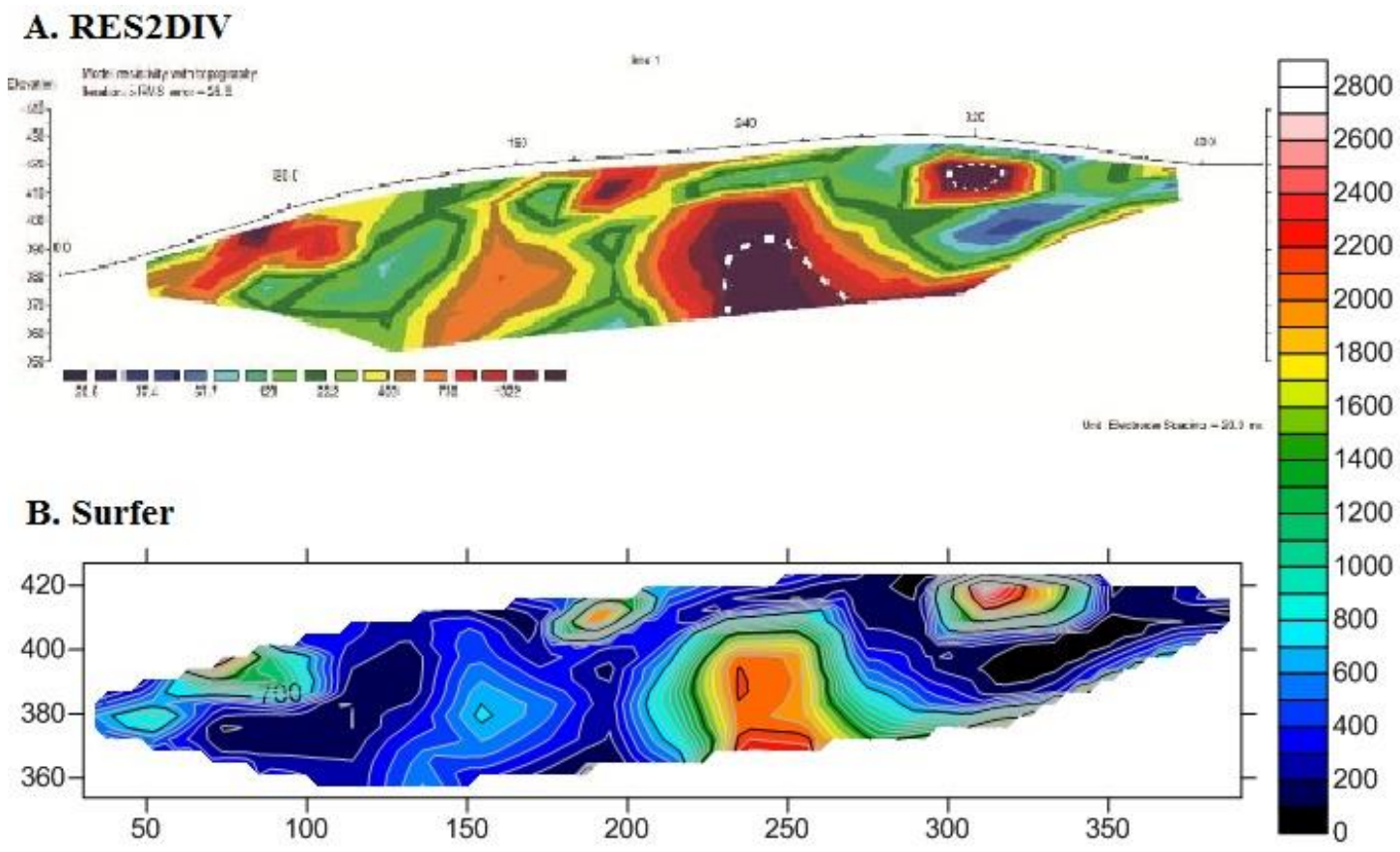

Figure2. 2D Geoelectric Interpretation of dipole-dipole results; A. Vertical interpretation of mapping using the Res2DIV software; B. Vertical interpretation of mapping using Surfer software

Environmental geophysical survey results and 2D Geoelectric interpretation

From the results of 2D geoelectric interpretation, students can explain the differences in rock resistivity and explain the characteristics of rock types (Wekke, et al., 2019). Although this assessment is based on presentations and discussions that we cannot prove in the form of data, we can prove in Figure 2, students can explain the characteristics of rocks based on differences in rock resistivity. In this case, students can interpret the data by using 2 software processing geoelectric data, namely Res2DIV and Surfer (Siregar \& Kurniawan, 2018). The management of the results of geoelectric data by using this 2 software, is intended to improve students' ability to process data and also in collaboration, improve socialization between groups (Putra, 2015). So, the results can be proven that the TGT type learning method, because the TGT type helps them in solving problems in the discussion (Widyawati, 2016).

\section{Normality test based on the results of the post-test}

Hypothesis:

$H_{0}$ : Data spreads normally

$H_{1}$ : Data does not spread normally

Table 5. Tests of normality

\begin{tabular}{cccccccc}
\hline \multirow{2}{*}{ Class } & \multicolumn{3}{c}{ Kolmogorov-Smirnov } & \multicolumn{3}{c}{ Shapiro-Wilk } \\
\cline { 3 - 8 } & & Statistic & df & Sig. & Statistic & df & Sig. \\
\hline Learning & Control Class & .249 & 10 & .079 & .905 & 10 & .248 \\
outcomes & Experiment Class & .223 & 10 & .175 & .895 & 10 & .193 \\
\hline
\end{tabular}

The probability of Kolmogorov Smirnov's output for the control class and experimental class is 0.079 and 0.175 respectively (Table 5). Since the value of Asymp. Sig. > 0.05, thus $\mathrm{H}_{0}$ is accepted or both the data are normally distributed so that one of the normal assumptions of the T-Test is fulfilled. 


\section{Homogeneity test based on post-test results}

Hypothesis:

$H_{0}$ : The two sample variances are the same
$H_{1}$ : The two sample variances are not the same

Table 6. The Test of Homogeneity of Variance

\begin{tabular}{llcccc}
\hline & & $\begin{array}{c}\text { Levene } \\
\text { Statistic }\end{array}$ & df1 & df2 & Sig. \\
\hline \multirow{4}{*}{$\begin{array}{l}\text { Learning } \\
\text { outcomes }\end{array}$} & Based on Mean & .003 & 1 & 18 & .955 \\
& Based on Median & .059 & 1 & 18 & .810 \\
& Based on Median and with & .059 & 1 & 16.834 & .811 \\
& adjusted df & & & & \\
& Based on trimmed mean & .009 & 1 & 18 & .927 \\
\hline
\end{tabular}

Based on table 6 , the results obtained from the test of homogeneity of variances in the Lavene Test Statistic, the sign value = 0.955 is higher than 0.05 which means that $\mathrm{H}_{0}$ is accepted so that it can be concluded that both sample variances are homogeneous and equal.

\section{T-test based on post-test results}

Besides the pre-test, the T-Test was also conducted in the Post Test. This is completed to figure out the difference of average in the control class and the experimental class, both before and after being given treatment. Therefore, after the prerequisite test is fulfilled which are the data of normal distributed and homogeneous, then T-test was carried out.

Based on the results of the SPSS calculation, the T-Test results are obtained,

Hypothesis:

$H_{0}$ :The average learning outcomes of both classes are the same

$H_{1}$ :There are differences in the average learning outcomes of both classes

Table 7. Independent samples test

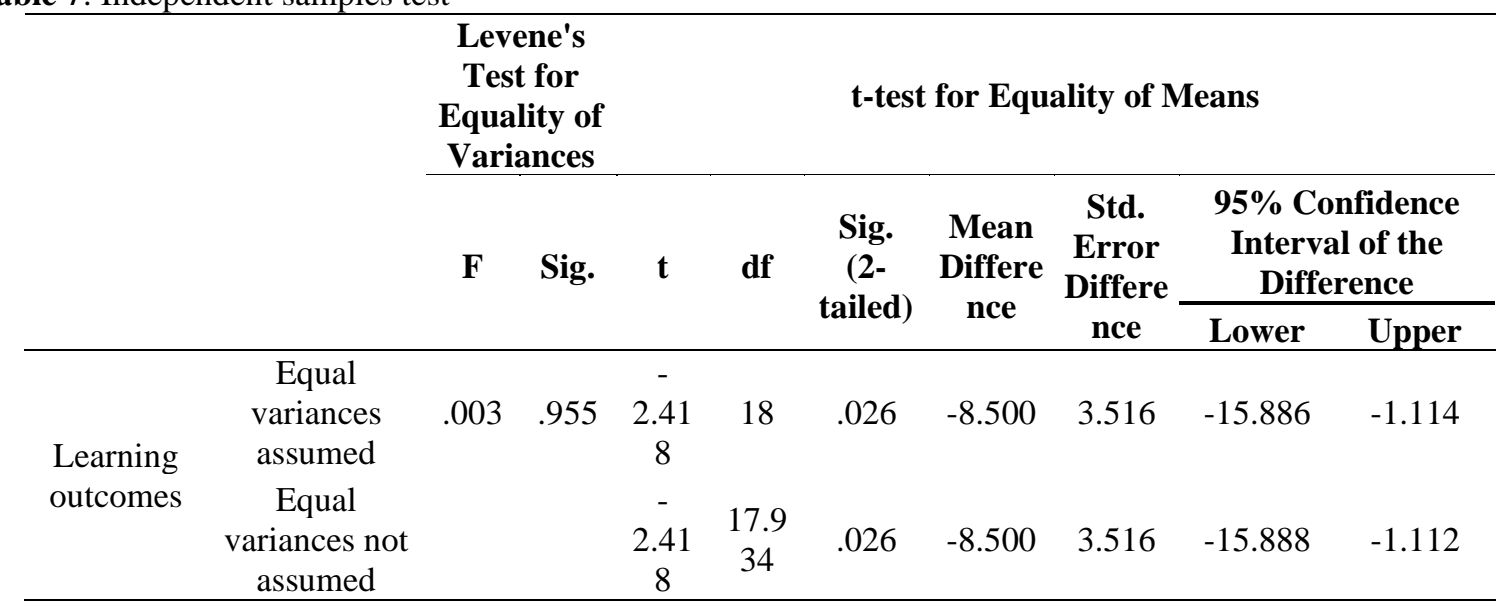




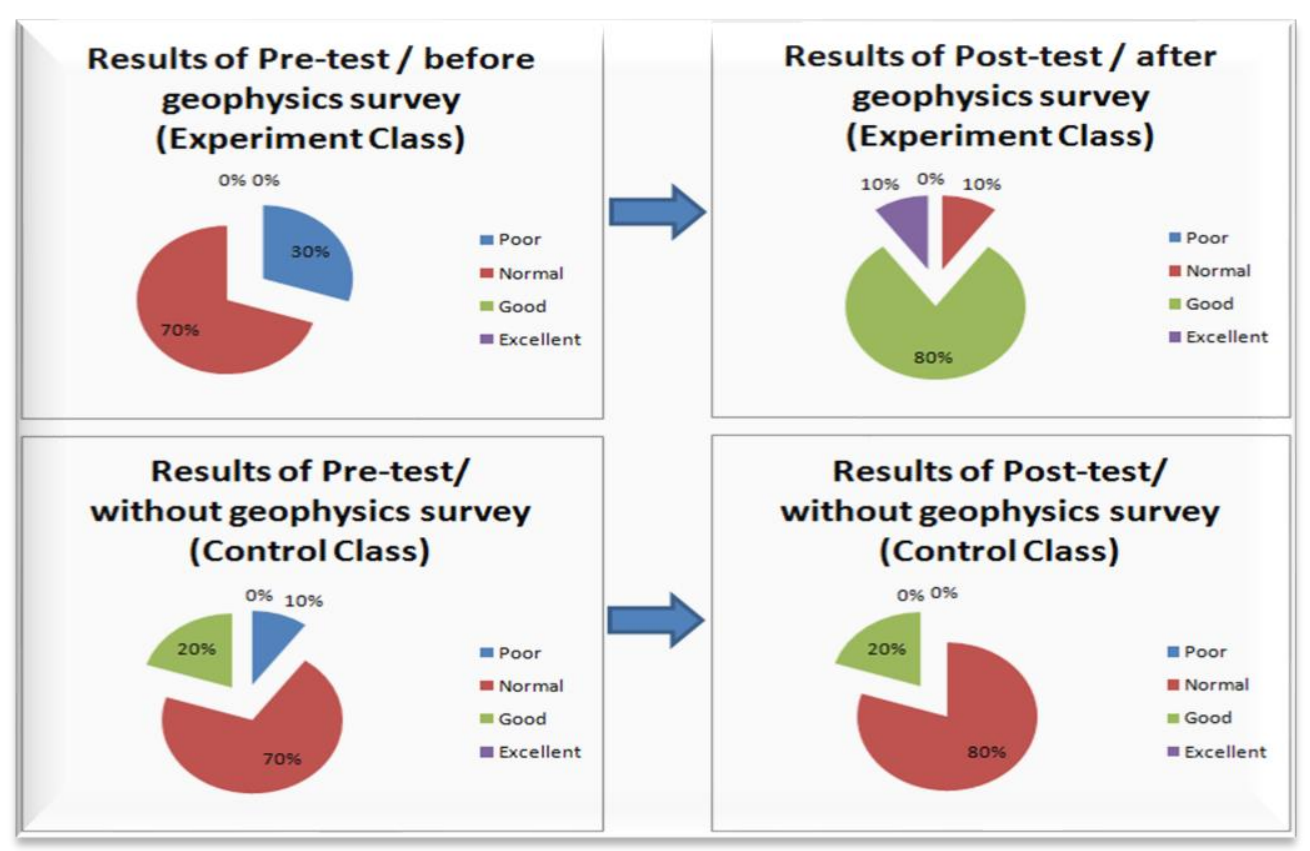

Figure 3. Percentage of comparison of pre-test and post-test results

Based on table 7 , the sign value $=0.026$ $<0.05$, so that $\mathrm{H}_{0}$ is rejected, which means there is a difference in the average learning outcomes of both classes.

\section{Discussion}

Based on the results of the pre-test and post-test, it was found that there were differences in the average between the control class and the experimental class. Also, the results of the post-test showed that the treatment given in the experimental class was successful (Abrami, Poulsen \& Chambers, 2010). The results showed that there is an increase in the percentage value of the pre-test and post-test results. The treatment has proven can provide a positive influence on all respondents (Wayan, Sri, Fadiawati \& Jalmo, 2018). These results explain that there is a positive effect of given treatment to the value obtained by each respondent.

In the control class, there seems to be no difference in the value obtained. It can be seen from the pre-test and post-test values that there has been an increase, steady, and decrease (Herpratiwi, 2018). Based on the explanation above, it shows that the treatment is necessary to be given. One of the treatments has influenced the respondents' score value. In the experimental class, all respondents obtained a score increase in the post-test. Whereas the control class with no treatment, the score has increased, steady, and decreased (Kusuma, 2017). Besides, based on the results of the calculations, the T-test explains that there is a difference in the average between the control class and the experimental class, which means that this study was successful (Tan \& So, 2018).

Furthermore, Figure 3 provided the comparison percentage of students' understanding between the experimental class and the control class, before and after the environmental geophysical survey is given, based on pre-test and post-test results. These results confirm that geophysical surveys with the concept of the TGT cooperative learning method can improve student understanding (Slavin, 2010).

\section{CONCLUSION}

The learning process with the TGT cooperative learning model is considered as an effective method to enhance students' achievement and understanding of electrodynamics theory with environmental 
geophysical practices. The concept of learning in groups and using the geophysical survey tools (geoelectric) influences students' understanding of the electrodynamics concept.

Furthermore, students can also play an active role in responding and arguing during the presentation and discussion of the geoelectric interpretation results. In this case, students can explain how the concept of geoelectric as well as the concept of electrical propagation. Students also can measure and distinguish rock resistivity. Furthermore, students can outline or create geoelectric surveys maps with $2 \mathrm{D}$ designs.

The excellent results of the TGT cooperative learning method effectiveness and the geoelectric practice were proven by the comparison of the results of the Normalization Test, Homogeneity Test, and $\mathrm{T}$-Test in the pre-test and post-test. The data about percentage comparison of the pre-test and post-test results in each class (Figure 3) indicates that the geoelectric practice with the TGT cooperative learning method succeeded to increase students' achievements in the understanding of electrodynamic theory.

\section{ACKNOWLEDGMENT}

Thank you for the laboratory of mining exploration at the Department of Mining Engineering, Institut Teknologi Nasional Yogyakarta, Yogyakarta, Indonesia.

\section{AUTHOR CONTRIBUTIONS}

RP looks for ideas and makes research designs. SH makes learning media. RU collects data and analyzes data. KJ calculates statistical data. AE analyzed the research data. HS and MS write the discussion and conclusion.

\section{REFERENCES}

Abdullah, S. (2010). Effects of Jigsaw II Technique on Academic Achievement and Attitudes to Written Expression Course. Educational Research and Reviews, 5(December), 777-787.
Abdurrahman, Saregar, A., \& Umam, R. (2018). Assesment Toward the Quantum Physics Concept Mastery of the Prospective Physics Teachers. Jurnal Pendidikan IPA Indonesia, 7(1), 34-40. https://doi.org/10.15294/jpii.v6i2.7239

Abrami, P. C., Poulsen, C., \& Chambers, B. (2010). Teacher Motivation to Implement an Educational Innovation: Factors Differentiating Users and NonUsers of Cooperative Learning, 3410. https://doi.org/10.1080/0144341032000 160146

Amato, L. G. D., \& Krasny, M. E. (2011). Outdoor Adventure Education: Applying Transformative Learning Theory to Understanding Instrumental Learning and Personal Growth in Environmental Education Outdoor Adventure Education: Applying Transformative Learning Theory to Understanding Instrumental. The Journal of Environmental Education, 8964.

https://doi.org/10.1080/00958964.2011. 581313

Becker, C., Lauterbach, G., Spengler, S., Dettweiler, U., \& Mess, F. (2017). Effects of Regular Classes in Outdoor Education Settings: A Systematic Review on Students' Learning, Social and Health Dimensions. International Journal of Environmental Research and Public Health, 14(5), 1-20. https://doi.org/10.3390/ijerph14050485

Bosschaart, A., Schee, J. Van Der, \& Kuiper, W. (2016). Designing a floodrisk education program in the. The Journal of Environmental Education, 47(4), 271-286. https://doi.org/10.1080/00958964.2015. 1130013

Cutter-mackenzie, A., \& Edwards, S. (2013). Toward a Model for Early Childhood Environmental Education: Foregrounding , Developing , and Connecting Knowledge Through PlayBased Learning. The Journal of 
Environmental Education, 8964(May). https://doi.org/10.1080/00958964.2012. 751892

Dubois, B., \& Krasny, M. E. (2016). Educating with Resilience in Mind: Addressing Climate Change in PostSandy New York City. The Journal of Environmental Education, 47(4), 255270.

https://doi.org/10.1080/00958964.2016. 1167004

Dunlap, R. E. (2010). The New Environmental Paradigm Scale: From Marginality to Worldwide Use. The Journal of Environmental Education, 8964.

https://doi.org/10.3200/JOEE.40.1.3-18

Dunlap, R. E., \& Liere, K. D. Van. (2014). The " New Environmental Paradigm ." The Journal of Environmental Education, $\quad$ 8964(May). https://doi.org/10.1080/00958964.1978. 10801875

Gillies, R. M. (2016). Cooperative learning: Review of research and practice. Australian Journal of Teacher Education, 41(3), 39-54. https://doi.org/10.14221/ajte.2016v41n 3.3

Haq, M. A., Najmonnisa, \& Saad, I. (2015). Impact of cooperative learning teaching methods on 7th grade students' academic achievement: An experimental study. Journal of Elementary Education, 25(2), 89-112.

Herpratiwi. (2018). The Effectiveness of the Inclusive Education Model for Students with Special Needs on Cognitive Learning Achievement. Jurnal Pendidikan Progresif, 8(2), 97-108. https://doi.org/10.23960/jpp.v8.i2.2018 11

Hines, J. M., Hungerford, H. R., \& Tomera, A. N. (2010). Analysis and Synthesis o f Research on Responsible Environmental Behavior: A MetaAnalysis. The Journal of Environmental Education, 8964. https://doi.org/10.1080/00958964.1987.
9943482

Kusuma, A. P. (2017). Implementasi Model Pembelajaran Student Teams Achievement Division (STAD) dan Team Assisted Individualization (TAI) ditinjau dari Kemampuan Spasial Siswa. Al-Jabar: Jurnal Pendidikan Matematika, 8(2), 135-144.

Lestari, F., Saryantono, B., Syazali, M., Saregar, A., Jauhariyah, D., \& Umam, R. (2019). Cooperative Learning Application with the Method of Network Tree Concept Map : Based on Japanese Learning System Approach. Journal for the Education of Gifted Young Scientists, 7(1), 15-32. https://doi.org/10.17478/jegys.471466

Maneejak, N. \& Yasri, P. (2018). "Nursing Students' Perception toward High Fidelity Simulation. PSAKU International Journal of Interdisciplinary Research, 7(2), 104111.

Meadows, M. (2016). Where Are All the Talented Girls? How Can We Help Them Achieve in Science Technology Engineering and Mathematics? Journal for the Education of Gifted Young, 4(December), 29-42.

Mehta, S., \& Kulshrestha, A. K. (2014). Implementation of Cooperative Learning in Science: A Developmentalcum-Experimental Study. Education Research International, 2014, 1-7. https://doi.org/10.1155/2014/431542

Parmin, P., Nuangchalerm, P., \& El, R. A. Z. (2019). Exploring the Indigenous Knowledge of Java North Coast Community (Pantura) Using the Science Integrated Learning (SIL) Model for Science Content Development. Journal for the Education of Gifted Young, 7(March), 71-83.

Pisanpanumas, P.\& Yasri, P. (2018). SOLO Taxonomy: Increased Complexity of Conceptual Understanding about the Interconnection between Convection and Natural Disasters Using Hands-On 
Activities. PSAKU International Journal of Interdisciplinary Research, 7(2), 91-103.

Pleasants, K. (2009). Learning from a review of research on outdoor learning. The Fourth International Outdoor Education Research Conference, (April), 15-18.

Putra, F. G. (2015). Eksperimentasi Model Pembelajaran Kooperatif Tipe Teams Games Tournament (TGT) Berbantuan Software Cabri 3d di Tinjau dari Kemampuan Koneksi Matematis Siswa Fredi Ganda Putra. Al-Jabar: Jurnal Pendidikan Matematika, 6(2), 143153.

Rickinson, M., Dillon, J., Teamey, K., Morris, M., Young Choi, M., Sanders, D., \& Benefield, P. (2004). A review of research on outdoor learning (Shrewsbury, UK, Field Studies Council). National Foundation for Educational Research, (March), 1-6.

Santi Widyawati. (2016). Pengaruh Gaya Belajar Terhadap Prestasi Belajar Mahasiswa Program Studi Pendidikan Matematika (IAIM NU) Metro. AlJabar : Jurnal Pendidikan Matematika, 7(1), 107-114.

Siregar, R. N., \& Kurniawan, W. B. (2018). 2D Interpretation Of Subsurface Hot Spring Geothermal Structure In Nyelanding Village Through Schlumberger Geoelectricity. Jurnal Ilmiah Pendidikan FisikaAl-BiRuNi, 7(April), 81-87. https://doi.org/10.24042/jipfalbiruni.v7 i1.2324

Slavin, R. E. (2010). Co-operative Learning: What Makes Group Work Work ?, 1-5.

Smith, W. (2019). The Role of Environment Clubs in Promoting Ecocentrism in Secondary Schools: Student Identity and Relationship to the Earth. The Journal of Environmental Education, 8964.

Tan, E., \& So, H. (2018). Role of environmental interaction in interdisciplinary thinking: from knowledge resources perspectives. The Journal of Environmental Education, O(0), 1-21. https://doi.org/10.1080/00958964.2018. 1531280

Wayan, N., Sri, N., Fadiawati, N., \& Jalmo, T. (2018). Improving the Students' Creative Thinking using Problem Based Worksheet on the Topic of Environmetal Pollution. Jurnal Pendidikan Progresif, 8(2), 127-137. https://doi.org/10.23960/jpp.v8.i2.2018 14

Wekke, I. S., Rajindra, R., Pushpalal, D., Samad, M. A., Yani, A., \& Umam, R. (2019). Educational Institution on Responding Disasters in Palu of Indonesia. INA-Rxiv Papers. https://doi.org/10.31227/osf.io/drc8q

Wekke, I. S., Sabara, Z., Samad, M. A., Yani, A., \& Umam, R. (2019). Earthquake, Tsunami, And Society Cooperation: Early Findings In Palu Post Of Indonesia Disaster. INA-Rxiv Papers. https://doi.org/10.31227/osf.io/xmcyn

Y1ldırım, G., \& Akamca, G. Ö. (2017). The effect of outdoor learning activities on the development of preschool children. South African Journal of Education, 37(2), 1-10. https://doi.org/10.15700/saje.v37n2a13 78

Yumusak, A., Maras, İ., \& Şahin, M. (2015). Effects of Computer-Assisted Instruction with Conceptual Change Texts on Removing the. Journal for the Education of Gifted Young, 3(December), 23-50.

Zaky, R. A., Islami, E., \& Nuangchalerm, P. (2018). Science Process of Environmental Conservation: A Cross National Study of Thai and Indonesian Pre-service Science Teachers. Journal for the Education of Gifted Young, 6(December), 72-80. 